\title{
Effect of a previous high hydrostatic pressure treatment on lipid damage in chilled Chilean jack mackerel (Trachurus murphyi)
}

\author{
By D. Maluenda ${ }^{1}$, T. Roco ${ }^{1}$, G. Tabilo-Munizaga ${ }^{2}$, M. Pérez-Won ${ }^{1}$ and S.P. Aubourg ${ }^{3, 凶}$ \\ ${ }^{1}$ Department of Food Engineering. University of La Serena. La Serena (Chile) \\ ${ }^{2}$ Department of Food Engineering. University of Bío-Bío. Chillán (Chile). \\ ${ }^{3}$ Department of Food Technology. Marine Research Institute (CSIC). Vigo (Spain) \\ Corresponding author: saubourg@iim.csic.es
}

\section{RESUMEN}

\begin{abstract}
Efecto de un tratamiento previo por altas presiones hidrostáticas sobre la alteración lipídica de jurel chileno (Trachurus murphyi) refrigerado
\end{abstract}

Se estudió la evolución de la alteración lipídica en jurel chileno (Trachurus murphyi) refrigerado previamente tratado a altas presiones hidrostáticas (HHP). Se aplicaron distintos valores de presión y tiempo de presurización; asimismo, se analizó de forma comparativa la respuesta al proceso del pescado inicial en estados pre- y post-rigor mortis (RM). El tratamiento previo por HHP produjo inhibición de la hidrólisis lipídica en pescado refrigerado, siendo más intenso el efecto de la presión que el del tiempo de presurización. De acuerdo con el análisis de distintos índices de oxidación, no se concluyó un efecto determinante sobre la oxidación lipídica por parte del tratamiento previo de HHP. En relación al efecto del estado de RM del pescado inicial, se observó una oxidación primaria y secundaria mayor en jurel correspondiente a la condición post-RM durante la conservación en refrigeración sin embargo, no se detectó un efecto claro sobre la hidrólisis lipídica.

PALABRAS CLAVE: Altas presiones - Hidrólisis lipídica - Oxidación lipídica - Refrigeración - Rigor mortis - Trachurus murphyi.

\section{SUMMARY}

Effect of a previous high hydrostatic pressure treatment on lipid damage in chilled Chilean jack mackerel (Trachurus murphyi)

Lipid damage evolution was analyzed in chilled Chilean jack mackerel (Trachurus murphyi) previously treated with high hydrostatic pressure (HHP) technology. Different pressure levels and pressure holding times were tested. In addition, fish corresponding to pre- and post-rigor mortis (RM) stages were comparatively studied. Previous HHP treatment led to a marked lipid hydrolysis inhibition in chilled fish. Increasing the pressure level and pressure holding time led to a lower free fatty acid content, with the effect of pressure being more relevant. According to the analysis of different types of lipid oxidation indexes, no effect of the previous HHP treatment on the lipid oxidation development could be determined in chilled jack mackerel. Concerning the effect of the RM stage of raw fish, a higher primary and secondary lipid oxidation development was observed in fish corresponding to the post-RM condition throughout the chilled storage; although a definite effect on lipid hydrolysis could not be found.

KEY-WORDS: Chilling - High pressure - Lipid hydrolysis - Lipid oxidation - Rigor mortis - Trachurus murphyi.

\section{INTRODUCTION}

Marine species are known to deteriorate rapidly postmortem due to the effects of a variety of degradation mechanisms (Whittle et al., 1990). The current increasing consumer demand for high quality fresh products has led to the development of advanced technologies. Among them, high hydrostatic pressure (HHP) technology has been reported to maintain sensory and nutritional properties, while inactivating microbial development and leading to a shelf-life extension and a safety improvement (Torres and Velázquez, 2005; Norton and Sun, 2008; Sánchez et al., 2012). This technology has shown a potential application in the seafood industry for the production of surimi and kamaboko (Montero et al., 1998), for coldsmoked fish preparation (Lakshmanan et al., 2007) and for aiding in freezing (Alizadeh et al., 2007), thawing (Rouillé et al., 2002) and thermal (Ramírez et al., 2009) processing. An additional positive effect of HHP treatment is that deteriorative hydrolytic (namely, lipases and phospholipases) and oxidative (peroxidases, lipoxygenases, etc.) endogenous enzymes can be inactivated for a further storage of the fish product (Ohshima et al., 1992). Thus, a profitable effect on quality retention has been observed when employed previously to a refrigerated (He et al., 2002; Erkan et al., 2010) or chilled (Hurtado et al., 2001; Ortea et al., 2010) storage.

Small pelagic fish species can constitute food products of great economic importance in many countries. Some of these fish species are captured in high proportions when their demand is relatively low, so that a large portion of their catches is underutilized and transformed into fish 
meals for animals. One such abundant species is Chilean jack mackerel (Trachurus murphyi). This underutilized fish is captured in large volumes in countries like Chile, China and Peru (FAO, 2007). Although a great interest has been accorded to its commercialization (Simpson et al., 2004), most efforts have been focused on its employment as a surimi-type product (Ortiz et al., 2004) and as a fish meal source (Bórquez and González, 1994). Studies on quality changes during refrigerated and chilled storage of this species appear to be scarce. Thus, microbiological activity during storage at room temperature or under refrigeration conditions has been studied (Schoebitz et al., 1985), and the inhibition of lipid damage and microbial activity during chilling storage was monitored by means of the application of essential oil (oregano and thyme) extracts (Quitral et al., 2009).

The quality characteristics of processed fish originating from pre- and post-rigor mortis (RM) raw material have been studied comparatively (Roth et al., 2006; Birkeland and Akse, 2010). However, the quality analysis has mainly been focused on sensory and physical properties, while lipid damage differences have been scarcely studied (Antipova and Smirnova, 1982; Duran et al., 2008). The present work concerns the lipid damage (hydrolysis and oxidation) development of Chilean jack mackerel during chilled storage. The study was aimed at investigating the effect of a previous HHP treatment, including different pressure levels and pressure holding times. In addition, the effect of the $\mathrm{RM}$ condition of the initial raw fish was analyzed.

\section{MATERIALS AND METHODS}

\subsection{Raw fish, processing and sampling}

Fresh Chilean jack mackerel fish (360 individuals; weight range: $0.8-1.0 \mathrm{~kg}$; length range: 28-30 cm) were obtained at the Coquimbo (IV Región, Chile) harbor, sacrificed in a water-ice mixture and transported to our laboratory within one hour after catch. Before the RM process was initiated, one half of the total fish (180 individuals) was beheaded, gutted, filleted and placed in individual flexible polyethylene bags in order to be submitted to the HHP process. The other half of the fish (180 individuals) was maintained in ice (1:1, fish:ice ratio); once the RM process was finished (12 hours), individuals were processed the same way as their counterparts from the pre-RM condition to be further submitted to the HHP process.

The high-pressure equipment employed consisted of a cylindrical loading container provided with a 2 liter-pilot unit (Avure Technologies Incorporated, Kent, WA, USA). For both kinds of fish individuals (pre- and post-RM stages), different pressure levels (250, 450 and $550 \mathrm{MPa})$ and pressure holding times ( 3 and 4 minutes) were applied at room temperature $\left(15 \pm 2^{\circ} \mathrm{C}\right)$. In all cases, water was employed as the pressurizing medium, working at a $17 \mathrm{MPa} / \mathrm{s}$ ramp rate; decompression time was less than $5 \mathrm{~s}$.

Once the HHP treatment was carried out, the fish were kept in ice (1:1, fish:ice ratio) in a temperate room $\left(4^{\circ} \mathrm{C}\right)$ and analyzed at days $0,2,6,10$ and 14 of chilled storage. The boxes used allowed for draining and the ice was renewed when needed. The fish without previous HHP treatment was also submitted to chilled storage and considered as the control. For each type of fish sample, three different batches or replicates $(n=3)$ were considered and analyzed independently throughout the chilled storage. Analyses were carried out on the lipid fraction extracted from the white muscle of the fish. For each sampling point, two individuals were considered, and their white muscle portions were pooled together.

The response to the HHP treatment of marine species has been reported to vary with species, chemical composition and size (Yagiz et al., 2007). On the basis of conditions developed (150-450 MPa for 0-5 min) in a previous research carried out on a related species (Atlantic mackerel, Scomber scombrus; Vázquez et al., 2013), the above mentioned conditions were chosen for the present investigation.

\subsection{Lipid extraction and lipid hydrolysis analysis}

Lipids were extracted according to the Bligh and Dyer (1959) method, by employing a single-phase solubilization of the lipids using a chloroformmethanol (1:1) mixture. Quantification results were expressed as $\mathrm{g}$ lipid $100 \mathrm{~g}^{-1}$ muscle.

Free fatty acid (FFA) content was determined in the lipid extract of the fish muscle according to the Lowry and Tinsley (1976) method based on complex formation with cupric acetatepyridine followed by spectrophotometric $(715 \mathrm{~nm})$ assessment (Beckman Coulter DU 640, London, UK). Results were expressed as g FFA $100 \mathrm{~g}^{-1}$ lipids.

\subsection{Lipid oxidation analysis}

The peroxide value (PV) was determined in the lipid extract by peroxide reduction with ferric thiocyanate, according to the Chapman and McKay (1949) method. Results were expressed as meq active oxygen $\mathrm{kg}^{-1}$ lipids.

The thiobarbituric acid index (TBA-i) was determined according to Vyncke (1970). This method is based on the reaction between a trichloracetic acid extract of the fish muscle and thiobarbituric acid. The contents of thiobarbituric acid reactive substances (TBARS) were spectrophotometrically measured at $532 \mathrm{~nm}$ and calculated from a standard curve using 1,1,3,3-tetraethoxy-propane (TEP). Results were expressed as mg malondialdehyde $\mathrm{kg}^{-1}$ muscle.

The formation of fluorescent compounds was determined by measurements at $393 / 463 \mathrm{~nm}$ and 
$327 / 415 \mathrm{~nm}$ as described by Aubourg and PérezMartín (1996). The relative fluorescence (RF) was calculated as follows: $R F=F / F_{s t}$, where $F$ is the fluorescence measured at each excitation/emission maximum, and $\mathrm{F}_{\mathrm{st}}$ is the fluorescence intensity of a quinine sulfate solution $\left(1 \mu \mathrm{g} \mathrm{mL}^{-1}\right.$ in $\left.0.05 \mathrm{M} \mathrm{H}_{2} \mathrm{SO}_{4}\right)$ at the corresponding wavelength. The fluorescence ratio (FR) was calculated as the ratio between the two $\mathrm{RF}$ values: $\mathrm{FR}=\mathrm{RF}_{393 / 463 \mathrm{~nm}} / \mathrm{RF}_{327 / 415 \mathrm{~nm}}$. The FR value was determined in the aqueous phase resulting from the lipid extraction (Bligh and Dyer, 1959).

\subsection{Statistical analysis}

Data $(n=3)$ obtained from the different lipid damage indexes were subjected to the one-way ANOVA method $(p<0.05)$ to explore differences as a result of the following parameters: pressure level, pressure holding time, RM stage and chilled storage time (Statsoft, Statistica, version 6.0, 2001); comparison of means was performed using a least-squares difference (LSD) method.

\section{RESULTS AND DISCUSSION}

\subsection{Lipid content assessment}

The lipid content of Chilean jack mackerel white muscle employed was found to be in the

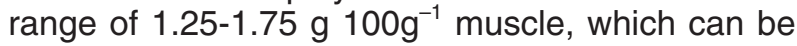
considered lower than the one previously reported for the same species (3.0-5.0 $\mathrm{g} / 100 \mathrm{~g}$ muscle) (Aranda et al., 2006; Quitral et al., 2009). No effect $(p>0.05)$ on the lipid content could be observed as a result of the HHP conditions (pressure level and pressure holding time) applied or the RM stage of fish individuals employed as starting raw material.

\subsection{Lipid hydrolysis development}

The results obtained for the FFA formation are included in Table 1. For both pre- and post-RM fish, a marked lipid hydrolysis inhibition $(p<0.05)$ throughout the chilled storage could be observed as a result of previously applying the two strongest pressures tested; for pre-RM samples, FFA values

Table 1

Free fatty acid (g $100 \mathrm{~g}^{-1}$ lipids) assessment* in chilled jack mackerel previously processed under different high pressure conditions**

\begin{tabular}{|c|c|c|c|c|c|c|c|c|c|}
\hline \multirow{3}{*}{$\begin{array}{l}\text { Chilling } \\
\text { storage time } \\
\text { (days) }\end{array}$} & \multirow{3}{*}{$\begin{array}{c}\text { Pressure } \\
\text { holding time } \\
\text { (minutes) }\end{array}$} & \multicolumn{8}{|c|}{ Pressure (MPa) } \\
\hline & & \multicolumn{4}{|c|}{ Pre-rigor mortis stage } & \multicolumn{4}{|c|}{ Post-rigor mortis stage } \\
\hline & & Control & 250 & 450 & 550 & Control & 250 & 450 & 550 \\
\hline \multirow{2}{*}{0} & 3 & $\begin{array}{l}1.84 \mathrm{c} \\
(0.03)\end{array}$ & $\begin{array}{l}1.63 \mathrm{~b} \\
(0.12)\end{array}$ & $\begin{array}{l}0.41 \mathrm{a} \\
(0.25)\end{array}$ & $\begin{array}{c}\text { y } 0.45 \mathrm{a} \\
(0.01)\end{array}$ & $\begin{array}{l}2.41 \mathrm{~b} \\
(0.47)\end{array}$ & $\begin{array}{l}2.62 \mathrm{~b} \\
(0.35)\end{array}$ & $\begin{array}{c}\text { y } 1.09 \mathrm{a} \\
(0.01)\end{array}$ & $\begin{array}{l}1.12 \mathrm{a} \\
(0.11)\end{array}$ \\
\hline & 4 & $\begin{array}{l}1.84 d \\
(0.03)\end{array}$ & $\begin{array}{l}1.30 \mathrm{c} \\
(0.45)\end{array}$ & $\begin{array}{l}0.46 \mathrm{~b} \\
(0.18)\end{array}$ & $\begin{array}{c}\text { z } 0.16 \text { a } \\
(0.02)\end{array}$ & $\begin{array}{l}2.41 \mathrm{~b} \\
(0.47)\end{array}$ & $\begin{array}{l}2.39 \mathrm{~b} \\
(0.55)\end{array}$ & $\begin{array}{c}z 0.81 \mathrm{a} \\
(0.13)\end{array}$ & $\begin{array}{l}0.90 \mathrm{a} \\
(0.11)\end{array}$ \\
\hline \multirow{2}{*}{2} & 3 & $\begin{array}{l}2.68 d \\
(0.12)\end{array}$ & $\begin{array}{c}\text { y } 1.97 \text { c } \\
(0.06)\end{array}$ & $\begin{array}{l}0.20 \mathrm{a} \\
(0.05)\end{array}$ & $\begin{array}{c}\text { y } 0.51 \text { b } \\
(0.09)\end{array}$ & $\begin{array}{l}2.02 \mathrm{c} \\
(0.02)\end{array}$ & $\begin{array}{l}1.43 \mathrm{~b} \\
(0.13)\end{array}$ & $\begin{array}{l}0.32 a \\
(0.12)\end{array}$ & $\begin{array}{l}0.38 \mathrm{a} \\
(0.01)\end{array}$ \\
\hline & 4 & $\begin{array}{l}2.68 d \\
(0.12)\end{array}$ & $\begin{array}{c}z 0.96 \text { c } \\
(0.15)\end{array}$ & $\begin{array}{l}0.18 a \\
(0.04)\end{array}$ & $\begin{array}{c}z 0.35 \mathrm{~b} \\
(0.01)\end{array}$ & $\begin{array}{l}2.02 \mathrm{c} \\
(0.02)\end{array}$ & $\begin{array}{l}1.59 \mathrm{~b} \\
(0.30)\end{array}$ & $\begin{array}{l}0.17 \mathrm{a} \\
(0.05)\end{array}$ & $\begin{array}{l}0.29 \mathrm{a} \\
(0.33)\end{array}$ \\
\hline \multirow{2}{*}{6} & 3 & $\begin{array}{l}4.89 d \\
(0.35)\end{array}$ & $\begin{array}{c}\text { y } 3.44 \text { c } \\
(0.02)\end{array}$ & $\begin{array}{c}\text { y } 0.28 \text { a } \\
(0.01)\end{array}$ & $\begin{array}{c}\text { y } 0.86 \text { b } \\
(0.14)\end{array}$ & $\begin{array}{l}3.17 \mathrm{c} \\
(0.15)\end{array}$ & $\begin{array}{c}\text { y } 2.15 \text { b } \\
(0.06)\end{array}$ & $\begin{array}{l}0.32 \mathrm{a} \\
(0.12)\end{array}$ & $\begin{array}{l}0.43 \mathrm{a} \\
(0.07)\end{array}$ \\
\hline & 4 & $\begin{array}{l}4.89 d \\
(0.35)\end{array}$ & $\begin{array}{c}\text { z } 1.15 \text { c } \\
(0.45)\end{array}$ & $\begin{array}{c}\text { z } 0.16 \text { a } \\
(0.01)\end{array}$ & $\begin{array}{c}z 0.43 b \\
(0.11)\end{array}$ & $\begin{array}{l}3.17 c \\
(0.15)\end{array}$ & $\begin{array}{c}\text { z } 1.66 \text { b } \\
(0.45)\end{array}$ & $\begin{array}{l}0.57 \mathrm{a} \\
(0.56)\end{array}$ & $\begin{array}{l}0.57 \mathrm{a} \\
(0.39)\end{array}$ \\
\hline \multirow{2}{*}{10} & 3 & $\begin{array}{l}5.78 d \\
(0.08)\end{array}$ & $\begin{array}{c}\text { y } 4.32 \text { c } \\
(0.04)\end{array}$ & $\begin{array}{l}0.39 a \\
(0.05)\end{array}$ & $\begin{array}{l}0.66 \mathrm{~b} \\
(0.00)\end{array}$ & $\begin{array}{l}4.03 c \\
(0.24)\end{array}$ & $\begin{array}{l}2.81 \mathrm{~b} \\
(0.11)\end{array}$ & $\begin{array}{l}0.83 a \\
(0.41)\end{array}$ & $\begin{array}{c}\text { y } 0.89 \text { a } \\
(0.25)\end{array}$ \\
\hline & 4 & $\begin{array}{l}5.78 d \\
(0.08)\end{array}$ & $\begin{array}{c}\text { z } 1.84 \text { c } \\
(0.23)\end{array}$ & $\begin{array}{l}0.33 a \\
(0.10)\end{array}$ & $\begin{array}{l}0.76 \mathrm{~b} \\
(0.09)\end{array}$ & $\begin{array}{l}4.03 d \\
(0.24)\end{array}$ & $\begin{array}{l}2.97 \mathrm{c} \\
(0.10)\end{array}$ & $\begin{array}{l}0.89 \mathrm{~b} \\
(0.11)\end{array}$ & $\begin{array}{c}\text { z } 0.32 \text { a } \\
(0.26)\end{array}$ \\
\hline \multirow{2}{*}{14} & 3 & $\begin{array}{l}6.86 \mathrm{~d} \\
(0.35)\end{array}$ & $\begin{array}{c}\text { y } 4.73 \text { c } \\
(0.23)\end{array}$ & $\begin{array}{l}0.54 \mathrm{a} \\
(0.10)\end{array}$ & $\begin{array}{l}1.19 \mathrm{~b} \\
(0.17)\end{array}$ & $\begin{array}{l}5.88 \mathrm{c} \\
(0.47)\end{array}$ & $\begin{array}{l}3.45 b \\
(0.84)\end{array}$ & $\begin{array}{l}0.93 \mathrm{a} \\
(0.03)\end{array}$ & $\begin{array}{l}0.84 \mathrm{a} \\
(0.53)\end{array}$ \\
\hline & 4 & $\begin{array}{l}6.86 d \\
(0.35)\end{array}$ & $\begin{array}{c}z 2.35 c \\
(0.03)\end{array}$ & $\begin{array}{l}0.70 \mathrm{a} \\
(0.10)\end{array}$ & $\begin{array}{l}1.07 \mathrm{~b} \\
(0.07)\end{array}$ & $\begin{array}{l}5.88 \mathrm{c} \\
(0.47)\end{array}$ & $\begin{array}{l}2.96 \mathrm{~b} \\
(0.08)\end{array}$ & $\begin{array}{l}0.98 \mathrm{a} \\
(0.12)\end{array}$ & $\begin{array}{l}1.06 \mathrm{a} \\
(0.05)\end{array}$ \\
\hline
\end{tabular}

* Mean values of three $(n=3)$ replicates; standard deviations are indicated in brackets.

${ }^{* *}$ For each chilling storage time, pressure holding time and rigor mortis stage, means followed by different letters (a-d) indicate significant $(p<0.05)$ differences as a result of pressure. For each chilling storage time, pressure and rigor mortis stage, mean values preceded by different letters $(z, y)$ indicate significant $(p<0.05)$ differences as a result of pressure holding time. No letters are indicated when significant differences are not found $(p>0.05)$. 
were found lower in 450-MPa fish than in their counterpart belonging to the $550-\mathrm{MPa}$ batch. A lower FFA content was also evident at chilling time 0 in HHP-treated fish, when compared to their counterpart control. This effect could be explained as a result of FFA interaction with other fish constituents during the HHP treatment, so that their extraction during the lipid fraction extraction could be partly prevented. This effect at chilling time 0 was found to increase with pressure and was more evident in pre-RM fish than in post-RM samples. This possible interaction would imply a volume decrease and agree with the Le Chatelier principle, which stipulates the chemical changes produced during HHP application.

The analysis of FFA values also shows an inhibitory effect $(p<0.05)$ on lipid hydrolysis development by means of increasing the pressure holding time in individuals corresponding to a pressure value of $250 \mathrm{MPa}$ and to the pre-RM stage. No effect $(p>0.05)$ on samples previously treated under higher pressures (450 and $550 \mathrm{MPa}$ ) could be concluded, probably as a consequence of the strong inhibitory effect developed by the pressure.

FFA have been reported to be mostly produced during the first stage of a chilling process (up to days 6-9, depending on several factors) as a result of endogenous enzyme (namely lipases and phospholipases) activity (Whittle et al., 1990). Later on, microbial activity should gain importance, so that FFA formation is then mostly produced as a result of bacterial catabolic processes (Chaouqy et al., 2008; Quitral et al., 2009). According to this profile, the present results on FFA formation in Chilean jack mackerel showed that a marked inhibition of both endogenous enzyme and microbial activities was produced by HHP conditions (namely, pressure level). On the other hand, FFA production as a direct effect of HHP treatment on higher-molecular-weight lipids (namely triglycerides and phospholipids) would not be expected to occur. Thus, a covalent bound breakdown would lead to a volume increase that should not be facilitated by an HHP treatment, according to the Le Châtelier principle (Norton and Sun, 2008).

Previous research concerning the effect of HHP treatment on FFA formation is scarce. An increased FFA content was observed in Coho salmon (Ortea et al., 2010), turbot (Chevalier et al., 2001) and carp (Sequeira-Muñoz et al., 2006) fillets after applying relatively low pressure values (100-200 MPa range). Higher pressure values are reported to be employed in experiments where a further storage was encountered; thus, $\mathrm{He}$ et al. (2002) did not observe inhibition of lipase activity in refrigerated $\left(4^{\circ} \mathrm{C}\right)$ oysters, which were previously pressurized at 207-310 MPa for 1-2 min. The same conclusion was attained by Gómez-Estaca et al. (2007) when studying cold-smoked sardine storage $\left(5^{\circ} \mathrm{C}\right.$ up to 21 days) previously treated under 300 $\mathrm{MPa}$ for $15 \mathrm{~min}$. However, in agreement with the present research, Ohshima et al. (1992) found that enzymatic degradation of phospholipids in cod muscle was successfully inhibited during storage $\left(-2{ }^{\circ} \mathrm{C}, 6\right.$ days) when a previous pressure of 400 $\mathrm{MPa}$ and over was applied for 15 and $30 \mathrm{~min}$.

The accumulation of FFA in fish muscle has no nutritional significance, but it is found undesirable due to secondary reactions, such as muscle texture changes, lipid oxidation enhancement and relation to off-odor development (Sikorski and Kolakowska, 1994; Refsgaard et al., 2000). In agreement to the present results obtained in the control samples, previous research on Chilean jack mackerel has shown an important lipid hydrolysis development during chilling (Roth et al., 2006) and frozen (Aranda et al., 2006) storage. Present results show that the employment of the HHP technology as a previous treatment to chilling storage can lead to a significant reduction in FFA formation and accordingly, to a quality enhancement.

Concerning the effect of the RM stage on FFA formation in the present experiment, a higher $(p<0.05)$ FFA content was obtained in post-RM individuals than in their pre-RM counterparts in all types of samples at chilling time 0 ; differences were higher in HHP-treated fish than in the control. In agreement with this difference, a considerable hydrolysis of triglycerides and phospholipids has already been reported to occur in stellate sturgeon during RM development (Antipova and Smirnova, 1982). Throughout the present chilled storage, differences found as a result of the RM stage were scarce and did not lead to a definite trend in any of the types of samples except for the control fish, where higher $(p<0.05)$ values were obtained in pre-RM fish.

\subsection{Primary lipid oxidation assessment}

This oxidation stage was analyzed by means of the PV assessment (Table 2). In all cases, a progressive peroxide formation could be observed throughout the chilled storage time. Lower mean $\mathrm{PV}$ could be observed in pre-RM fish when 250- and 450-MPa pressures were previously applied; differences with the control were found significant $(p<0.05)$ for the 0-2-day and 0-6-day periods, respectively. Meanwhile, a pro-oxidant effect $(p<0.05)$ could be depicted in pre-RM fish previously treated under $550 \mathrm{MPa}$ in the 10-14day period. For post-RM samples, a definite effect of the previous pressure applied on the peroxide formation could not be concluded.

Concerning the effect of the pressure holding time applied, pre- and post-RM samples corresponding to 250- and 450-MPa conditions showed a pro-oxidant effect $(p<0.05)$ by increasing the pressure holding time in fish corresponding to the 6-14-day chilling time; a definite effect of this factor could not be concluded for 550-MPa samples.

Previous research focusing on the effect of HHP treatment on the formation of primary oxidation compounds is scarce and unclear. Thus, Ohshima 
Table 2

Peroxide value (meq oxygen kg $^{-1}$ lipids) assessment* in chilled jack mackerel previously processed under high pressure conditions ${ }^{\star *}$

\begin{tabular}{|c|c|c|c|c|c|c|c|c|c|}
\hline \multirow{3}{*}{$\begin{array}{l}\text { Chilling } \\
\text { storage time } \\
\text { (days) }\end{array}$} & \multirow{3}{*}{$\begin{array}{c}\text { Pressure } \\
\text { holding time } \\
\text { (minutes) }\end{array}$} & \multicolumn{8}{|c|}{ Pressure (MPa) } \\
\hline & & \multicolumn{4}{|c|}{ Pre-rigor mortis stage } & \multicolumn{4}{|c|}{ Post-rigor mortis stage } \\
\hline & & Control & 250 & 450 & 550 & Control & 250 & 450 & 550 \\
\hline \multirow{2}{*}{0} & 3 & $\begin{array}{l}2.50 \mathrm{c} \\
(0.14)\end{array}$ & $\begin{array}{c}\text { y } 1.15 \mathrm{a} \\
(0.07)\end{array}$ & $\begin{array}{c}y 1.13 \mathrm{a} \\
(0.31)\end{array}$ & $\begin{array}{c}z 1.55 b \\
(0.05)\end{array}$ & $\begin{array}{l}1.90 \mathrm{a} \\
(0.04)\end{array}$ & $\begin{array}{l}2.51 \mathrm{~b} \\
(0.23)\end{array}$ & $\begin{array}{c}z 2.89 b \\
(0.29)\end{array}$ & $\begin{array}{c}\text { y } 3.73 \text { c } \\
(0.11)\end{array}$ \\
\hline & 4 & $\begin{array}{l}2.50 \mathrm{~b} \\
(0.14)\end{array}$ & $\begin{array}{c}\text { z } 0.60 \mathrm{a} \\
(0.07)\end{array}$ & $\begin{array}{c}z 0.58 \mathrm{a} \\
(0.04)\end{array}$ & $\begin{array}{c}\text { y } 2.97 \text { c } \\
(0.05)\end{array}$ & $\begin{array}{l}1.90 \mathrm{~b} \\
(0.04)\end{array}$ & $\begin{array}{l}2.48 \mathrm{c} \\
(0.56)\end{array}$ & $\begin{array}{c}\text { y } 4.85 \mathrm{~d} \\
(1.59)\end{array}$ & $\begin{array}{c}\text { z } 1.68 \mathrm{a} \\
(0.02)\end{array}$ \\
\hline \multirow{2}{*}{2} & 3 & $\begin{array}{l}4.40 \mathrm{c} \\
(0.39)\end{array}$ & $\begin{array}{c}2.50 \mathrm{a} \\
(0.03)\end{array}$ & $\begin{array}{c}2.13 \mathrm{a} \\
(0.62)\end{array}$ & $\begin{array}{c}z 3.43 \text { b } \\
(0.30)\end{array}$ & $\begin{array}{l}4.77 \mathrm{a} \\
(0.53)\end{array}$ & $\begin{array}{c}5.12 \mathrm{ab} \\
(0.73)\end{array}$ & $\begin{array}{c}\text { z } 4.37 \mathrm{a} \\
(0.38)\end{array}$ & $\begin{array}{c}\text { y } 6.37 \text { b } \\
(0.90)\end{array}$ \\
\hline & 4 & $\begin{array}{l}4.40 \mathrm{c} \\
(0.39)\end{array}$ & $\begin{array}{l}2.46 \mathrm{a} \\
(0.18)\end{array}$ & $\begin{array}{l}2.89 \mathrm{~b} \\
(0.11)\end{array}$ & $\begin{array}{c}\text { y } 4.62 \text { c } \\
(0.18)\end{array}$ & $\begin{array}{l}4.77 \mathrm{~b} \\
(0.53)\end{array}$ & $\begin{array}{l}4.78 \mathrm{~b} \\
(0.16)\end{array}$ & $\begin{array}{c}\text { y } 8.79 \text { c } \\
(0.11)\end{array}$ & $\begin{array}{c}\text { z } 3.12 \text { a } \\
(0.27)\end{array}$ \\
\hline \multirow{2}{*}{6} & 3 & $\begin{array}{l}8.63 c \\
(0.02)\end{array}$ & $\begin{array}{c}z 7.50 b \\
(0.18)\end{array}$ & $\begin{array}{c}\text { z } 6.32 \text { a } \\
(0.02)\end{array}$ & $\begin{array}{c}\text { y } 9.18 \text { c } \\
(1.89)\end{array}$ & $\begin{array}{c}14.53 \mathrm{~b} \\
(2.05)\end{array}$ & $\begin{array}{c}\text { z } 8.59 \text { a } \\
(0.25)\end{array}$ & $\begin{array}{c}\text { z } 9.12 \text { a } \\
(0.51)\end{array}$ & $\begin{array}{c}y 12.83 \mathrm{~b} \\
(1.88)\end{array}$ \\
\hline & 4 & $\begin{array}{l}8.63 c \\
(0.02)\end{array}$ & $\begin{array}{c}\text { y } 9.03 \text { bc } \\
(1.14)\end{array}$ & $\begin{array}{c}\text { y } 7.77 \mathrm{ab} \\
(0.54)\end{array}$ & $\begin{array}{c}\text { z } 6.61 \mathrm{a} \\
(1.28)\end{array}$ & $\begin{array}{c}14.53 \mathrm{c} \\
(2.05)\end{array}$ & $\begin{array}{c}\text { y } 11.19 \text { b } \\
(0.68)\end{array}$ & $\begin{array}{c}\text { y } 15.35 \text { c } \\
(0.85)\end{array}$ & $\begin{array}{c}\text { z } 6.56 \mathrm{a} \\
(0.51)\end{array}$ \\
\hline \multirow{2}{*}{10} & 3 & $\begin{array}{c}10.38 \mathrm{a} \\
(2.32)\end{array}$ & $\begin{array}{c}\text { z } 10.27 \mathrm{a} \\
(1.20)\end{array}$ & $\begin{array}{c}\text { z } 9.20 \text { a } \\
(0.34)\end{array}$ & $\begin{array}{c}y 18.42 b \\
(0.31)\end{array}$ & $\begin{array}{c}15.49 \mathrm{~b} \\
(1.38)\end{array}$ & $\begin{array}{c}\text { z } 9.77 \text { a } \\
(0.54)\end{array}$ & $\begin{array}{c}\text { z } 9.27 \text { a } \\
(1.22)\end{array}$ & $\begin{array}{c}y 14.75 \text { b } \\
(1.71)\end{array}$ \\
\hline & 4 & $\begin{array}{c}10.38 \mathrm{a} \\
(2.32)\end{array}$ & $\begin{array}{c}\text { y } 15.56 \text { bc } \\
(1.68)\end{array}$ & $\begin{array}{c}y 13.05 \mathrm{ab} \\
(1.30)\end{array}$ & $\begin{array}{c}z 16.11 \mathrm{c} \\
(0.28)\end{array}$ & $\begin{array}{c}15.49 \mathrm{~b} \\
(1.38)\end{array}$ & $\begin{array}{c}\text { y } 15.31 \text { b } \\
(0.87)\end{array}$ & $\begin{array}{c}\text { y } 16.59 \mathrm{~b} \\
(2.06)\end{array}$ & $\begin{array}{c}\text { z } 8.22 \mathrm{a} \\
(1.94)\end{array}$ \\
\hline \multirow[b]{2}{*}{14} & 3 & $\begin{array}{c}18.08 \mathrm{~b} \\
(1.13)\end{array}$ & $\begin{array}{c}\text { z } 16.83 \mathrm{a} \\
(0.22)\end{array}$ & $\begin{array}{c}z 15.98 \mathrm{a} \\
(0.25)\end{array}$ & $\begin{array}{c}26.39 \mathrm{c} \\
(0.04)\end{array}$ & $\begin{array}{c}25.12 \text { c } \\
(3.36)\end{array}$ & $\begin{array}{c}\text { z } 19.06 \text { b } \\
(0.09)\end{array}$ & $\begin{array}{c}z 13.73 \mathrm{a} \\
(0.99)\end{array}$ & $\begin{array}{c}z 12.57 \mathrm{a} \\
(0.35)\end{array}$ \\
\hline & 4 & $\begin{array}{c}18.08 \mathrm{a} \\
(1.13)\end{array}$ & $\begin{array}{c}y 22.94 \text { b } \\
(0.21)\end{array}$ & $\begin{array}{c}y 18.04 \mathrm{a} \\
(0.29)\end{array}$ & $\begin{array}{c}28.24 \mathrm{c} \\
(1.99)\end{array}$ & $\begin{array}{c}25.12 b c \\
(3.36)\end{array}$ & $\begin{array}{c}\text { y } 26.94 \text { c } \\
(1.24)\end{array}$ & $\begin{array}{c}y 19.78 \\
a b \\
(3.25)\end{array}$ & $\begin{array}{c}\text { y } 20.76 \text { a } \\
(0.39)\end{array}$ \\
\hline
\end{tabular}

* Mean values of three $(n=3)$ replicates; standard deviations are indicated in brackets.

${ }^{* *}$ For each chilling storage time, pressure holding time and rigor mortis stage, means followed by different letters (a-d) indicate significant $(p<0.05)$ differences as a result of pressure. For each chilling storage time, pressure and rigor mortis stage, mean values preceded by different letters $(z, y)$ indicate significant $(p<0.05)$ differences as a result of pressure holding time. No letters are indicated when significant differences are not found $(p>0.05)$.

et al. (1992) showed that the peroxide content of cod and mackerel muscle increased by applying an increasing pressure value (a 200-600 MPa range for 15 and $30 \mathrm{~min}$ ). A similar conclusion was obtained in a model system including sardine lipids (Tanaka et al., 1991); thus, an increasing PV was attained throughout storage $\left(5^{\circ} \mathrm{C}\right.$ up to 4 days) as a result of a previous HHP treatment (150 MPa for 15 and $30 \mathrm{~min}$ ). On the contrary, a partial inhibition of peroxide formation was observed in Coho salmon during the chilled storage when a previous HHP treatment (170 and $200 \mathrm{MPa}$ for $30 \mathrm{~s}$ ) was applied (Aubourg et al., 2010).

Concerning the effect of the RM stage of the initial raw fish, a higher PV $(p<0.05)$ was obtained in pre-RM control individuals than in their post-RM counterparts (chilling time 0). On the other hand, higher peroxide levels $(p<0.05$ ) were obtained at that time in post-RM fish when 250- and 450$\mathrm{MPa}$ pressures (both for 3 or 4 minutes) were previously applied. Throughout the chilled storage, post-RM fish showed higher mean peroxide levels when control, 250- and 450-MPa samples were considered; in the case of 550-MPa fish, higher
( $p<0.05)$ peroxide levels were found for pre-RM fish in the 10-14-day period.

Pre-RM fish showed a PV lower than score 10 for the 0-6-day period for all types of samples. In fact, fish samples corresponding to 450-MPa and 3-min conditions were still under this mark after 10 days of chilled storage. In the case of post-RM fish, a PV under 10 was only obtained for the 0-2-day interval, with samples from 250- and 450-MPa and 3-min still under this value for the 0-10-day period.

\subsection{Secondary lipid oxidation assessment}

Results related to the formation of TBARS can be observed in Figures 1-2. Samples corresponding to a previous 250-MPa treatment were lost so that analyses could not be done. In all types of samples analyzed, a progressive formation of such type of compounds could be observed throughout the chilling time. This result agrees with the above mentioned general increase detected for peroxide formation (Table 1).

No effect $(p>0.05)$ of the pressure applied could be concluded at chilling time 0 for pre-RM 
fish (Figure 1). However, a higher mean TBARS formation was detected at that time in HHPtreated post-RM fish when compared to control samples (Figure 2), and this effect is the result of HHP treatment on the lipid fraction; significant differences were found ( $p<0.05$ ) for 550-MPatreated fish. Throughout the chilled storage, all kinds of HHP-treated fish led to a higher mean TBA-i than their corresponding control; differences were found to be significant $(p<0.05)$ at day 6 and days 2 and 6 for samples previously treated under 450 and $550 \mathrm{MPa}$, respectively. A definite effect of the pressure holding time (comparison between 3 and 4 minute treatments) could not be concluded $(p>0.05)$ for the TBARS formation in either pre- or post-RM fish, whatever the pressure applied was.

Contradictory conclusions have been reported concerning the effect of HHP treatment on the
TBA-i. Thus, an increase as a result of HHP treatment has been observed for carp (SequeiraMuñoz et al., 2006) and turbot (Chevalier et al., 2001) fillets, both showing an increasing effect with pressure holding time. However, no differences in TBARS formation were observed for horse mackerel (Erkan et al., 2011) or Atlantic salmon (Amanatidou et al., 2000).

Contradictory results have also been observed when evaluating the effect of a previous HHP treatment on TBARS formation throughout a further storage. Thus, an increase was observed in chilled rainbow trout (Yagiz et al., 2007) and Coho salmon (Aubourg et al., 2010), cold-smoked salmon (Lakshmanan et al., 2007), refrigerated $\left(4^{\circ} \mathrm{C}\right) \mathrm{cod}$ muscle (Angsupanich and Ledward, 1998) and stored $\left(-2^{\circ} \mathrm{C}\right)$ cod and mackerel muscle (Ohshima et al., 1992). Opposite results were obtained however,

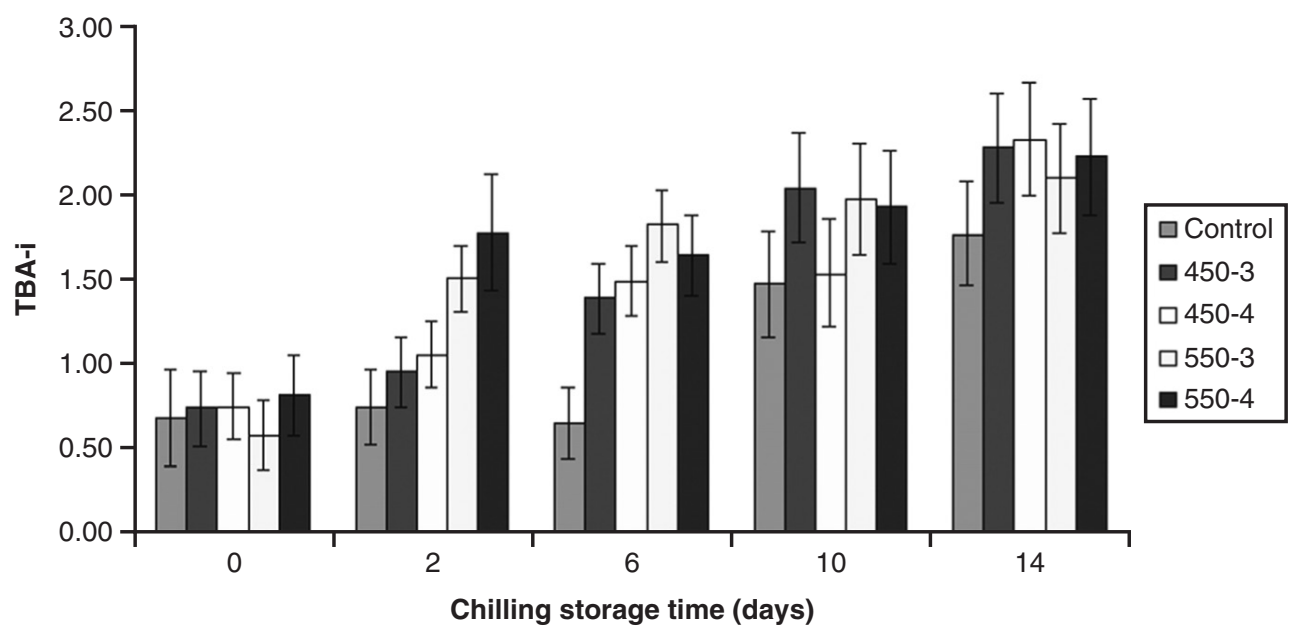

Figure 1

Evolution of the thiobarbituric acid index (TBA-i) (mg malondialdehyde $\mathrm{kg}^{-1}$ muscle) $)^{*}$ in chilled pre-rigor mortis Chilean jack mackerel previously processed under different high hydrostatic pressure (HHP) conditions ${ }^{* \star}$ * Mean values of three $(n=3)$ replicates; standard deviations are indicated by bars.

** HHP treatment abbreviations: 450-3 (450 MPa/3 min), 450-4 (450 MPa/4 min), 550-3 (550 MPa/3 min), 550-4 (550 MPa/4 min). Control: No HHP treatment.

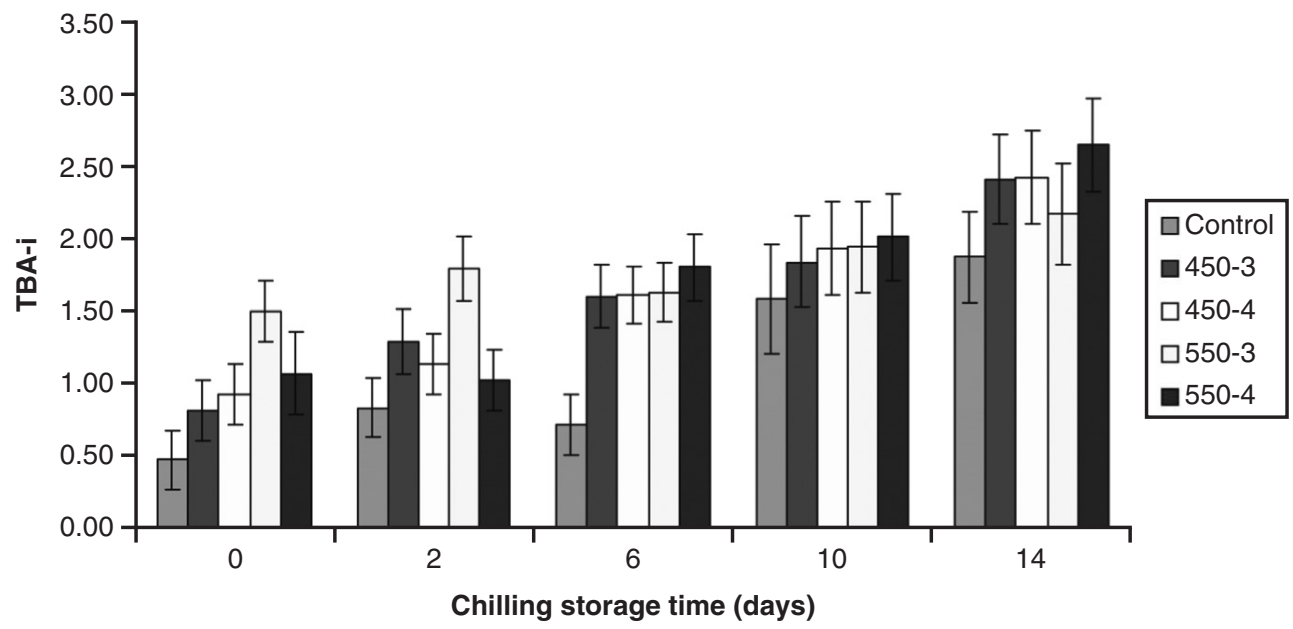

Figure 2

Evolution of the thiobarbituric acid index (TBA-i) (mg malondialdehyde $\mathrm{kg}^{-1}$ muscle) $)^{*}$ in chilled post-rigor mortis Chilean jack mackerel previously processed under different high hydrostatic pressure (HHP) conditions**

${ }^{*}$ Mean values of three $(n=3)$ replicates; standard deviations are indicated by bars.

${ }^{\star *} \mathrm{HHP}$ treatment abbreviations as expressed in Figure 1. 
by Ramírez-Suárez and Morrisey (2006) when minced albacore muscle was HHP-treated and then refrigerated at $4^{\circ} \mathrm{C}$; thus, a lower TBARS formation was found in HHP-treated fish than in control ones. An inhibitory effect on TBA-i score was also attained in red mullet muscle throughout refrigerated $\left(4^{\circ} \mathrm{C}\right)$ storage (Erkan et al., 2010).

Regarding the effect of the RM stage in the present research, a higher mean TBARS formation was detected in pre-RM control samples when compared to their post-RM counterparts at chilling time 0 . However, if HHP-treated fish are considered at that time, a higher mean formation in post-RM fish was found in all cases; this difference was found to be significant $(p<0.05)$ in the case of 550-MPa-3-min treatment. Throughout the chilled storage, higher mean TBA-i values were obtained in most cases in samples belonging to the postRM condition; however, differences were not found to be significant $(p>0.05)$. In agreement with the present research, lower TBA-i values were reported for fillets obtained from pre-RM rainbow trout and carp than in their post-RM counterparts (Duran et al., 2008).

\subsection{Assessment of interaction compound formation}

The formation of interaction compounds (FR assessment; Table 3) throughout the chilled storage was found lower than for primary (Table 2) and secondary (Figures 1-2) lipid oxidation compounds; thus, a significant $(p<0.05)$ FR increase with time was only found in the longest storage period (10-14-day interval) for all types of samples. This lower formation can be explained on the basis that interaction compounds would mainly be formed once primary and secondary oxidized lipids (namely, electrophilic compounds) have been produced and have then reacted with proteintype molecules (namely, nucleophilic compounds) (Aubourg, 1999; Tironi et al., 2002).

Lower mean FR values were obtained in HHPtreated fish than in their counterpart controls at chilling time 0 , this effect being attributable to chemical modifications by HHP treatment of the fluorescent compounds measured; and significant differences were found $(p<0.05)$ in most cases, whatever the pressure, pressure holding time or RM stage condition is considered. However,

Table 3

Fluorescent compound formation* in chilled jack mackerel previously processed under different high pressure conditions ${ }^{* *}$

\begin{tabular}{|c|c|c|c|c|c|c|c|c|c|}
\hline \multirow{3}{*}{$\begin{array}{l}\text { Chilling } \\
\text { storage time } \\
\text { (days) }\end{array}$} & \multirow{3}{*}{$\begin{array}{c}\text { Pressure } \\
\text { holding time } \\
\text { (minutes) }\end{array}$} & \multicolumn{8}{|c|}{ Pressure (MPa) } \\
\hline & & \multicolumn{4}{|c|}{ Pre-rigor mortis stage } & \multicolumn{4}{|c|}{ Post-rigor mortis stage } \\
\hline & & Control & 250 & 450 & 550 & Control & 250 & 450 & 550 \\
\hline \multirow{2}{*}{0} & 3 & $\begin{array}{l}0.44 \mathrm{~b} \\
(0.07)\end{array}$ & $\begin{array}{l}0.21 \mathrm{a} \\
(0.06)\end{array}$ & $\begin{array}{l}0.23 a \\
(0.02)\end{array}$ & $\begin{array}{l}0.25 a \\
(0.08)\end{array}$ & $\begin{array}{l}0.32 \mathrm{c} \\
(0.11)\end{array}$ & $\begin{array}{c}0.20 \mathrm{bc} \\
(0.02)\end{array}$ & $\begin{array}{l}0.18 \mathrm{~b} \\
(0.00)\end{array}$ & $\begin{array}{l}0.14 \mathrm{a} \\
(0.02)\end{array}$ \\
\hline & 4 & $\begin{array}{l}0.44 \mathrm{~b} \\
(0.07)\end{array}$ & $\begin{array}{l}0.30 \mathrm{a} \\
(0.02)\end{array}$ & $\begin{array}{c}0.38 \mathrm{ab} \\
(0.11)\end{array}$ & $\begin{array}{c}0.33 \mathrm{ab} \\
(0.19)\end{array}$ & $\begin{array}{l}0.32 \mathrm{~b} \\
(0.11)\end{array}$ & $\begin{array}{l}0.14 \mathrm{a} \\
(0.03)\end{array}$ & $\begin{array}{l}0.18 \mathrm{a} \\
(0.02)\end{array}$ & $\begin{array}{l}0.14 \mathrm{a} \\
(0.01)\end{array}$ \\
\hline \multirow{2}{*}{2} & 3 & $\begin{array}{l}0.37 \mathrm{~b} \\
(0.08)\end{array}$ & $\begin{array}{c}\text { z } 0.20 \text { a } \\
(0.02)\end{array}$ & $\begin{array}{c}\text { z } 0.19 \text { a } \\
(0.03)\end{array}$ & $\begin{array}{c}\text { y } 0.40 \text { b } \\
(0.00)\end{array}$ & $\begin{array}{c}0.26 \\
(0.01)\end{array}$ & $\begin{array}{c}0.23 \\
(0.03)\end{array}$ & $\begin{array}{c}0.22 \\
(0.03)\end{array}$ & $\begin{array}{c}0.24 \\
(0.00)\end{array}$ \\
\hline & 4 & $\begin{array}{c}0.37 \\
(0.08)\end{array}$ & $\begin{array}{l}\text { y } 0.37 \\
(0.06)\end{array}$ & $\begin{array}{l}\text { y } 0.31 \\
(0.07)\end{array}$ & $\begin{array}{l}z 0.15 \\
(0.06)\end{array}$ & $\begin{array}{l}0.26 \mathrm{~b} \\
(0.01)\end{array}$ & $\begin{array}{l}0.19 \mathrm{a} \\
(0.04)\end{array}$ & $\begin{array}{c}0.28 \mathrm{ab} \\
(0.08)\end{array}$ & $\begin{array}{c}0.26 \mathrm{ab} \\
(0.04)\end{array}$ \\
\hline \multirow{2}{*}{6} & 3 & $\begin{array}{c}0.34 \\
(0.02)\end{array}$ & $\begin{array}{c}0.32 \\
(0.06)\end{array}$ & $\begin{array}{c}0.30 \\
(0.04)\end{array}$ & $\begin{array}{c}0.25 \\
(0.00)\end{array}$ & $\begin{array}{l}0.46 \mathrm{~b} \\
(0.08)\end{array}$ & $\begin{array}{l}0.37 \mathrm{a} \\
(0.00)\end{array}$ & $\begin{array}{l}0.36 \mathrm{a} \\
(0.06)\end{array}$ & $\begin{array}{l}0.34 \mathrm{a} \\
(0.02)\end{array}$ \\
\hline & 4 & $\begin{array}{c}0.34 \\
(0.02)\end{array}$ & $\begin{array}{c}0.41 \\
(0.05)\end{array}$ & $\begin{array}{c}0.35 \\
(0.07)\end{array}$ & $\begin{array}{c}0.31 \\
(0.05)\end{array}$ & $\begin{array}{c}0.46 \\
(0.08)\end{array}$ & $\begin{array}{c}0.34 \\
(0.10)\end{array}$ & $\begin{array}{c}0.42 \\
(0.04)\end{array}$ & $\begin{array}{c}0.39 \\
(0.03)\end{array}$ \\
\hline \multirow{2}{*}{10} & 3 & $\begin{array}{l}0.43 \mathrm{a} \\
(0.02)\end{array}$ & $\begin{array}{c}z 0.49 b \\
(0.01)\end{array}$ & $\begin{array}{c}\text { z } 0.39 \text { a } \\
(0.00)\end{array}$ & $\begin{array}{c}\text { y } 0.55 \text { b } \\
(0.04)\end{array}$ & $\begin{array}{c}0.63 \\
(0.03)\end{array}$ & $\begin{array}{c}0.61 \\
(0.03)\end{array}$ & $\begin{array}{l}\text { y } 0.61 \\
(0.06)\end{array}$ & $\begin{array}{c}0.59 \\
(0.02)\end{array}$ \\
\hline & 4 & $\begin{array}{l}0.43 \mathrm{a} \\
(0.02)\end{array}$ & $\begin{array}{c}\text { y } 0.67 \text { c } \\
(0.02)\end{array}$ & $\begin{array}{c}\text { y } 0.51 \text { b } \\
(0.01)\end{array}$ & $\begin{array}{c}z 0.45 \text { a } \\
(0.03)\end{array}$ & $\begin{array}{l}0.63 c \\
(0.03)\end{array}$ & $\begin{array}{c}0.54 \mathrm{bc} \\
(0.05)\end{array}$ & $\begin{array}{c}\text { z } 0.47 \text { b } \\
(0.01)\end{array}$ & $\begin{array}{l}0.41 \mathrm{a} \\
(0.00)\end{array}$ \\
\hline \multirow[b]{2}{*}{14} & 3 & $\begin{array}{l}0.73 \mathrm{~b} \\
(0.11)\end{array}$ & $\begin{array}{c}\text { z } 0.62 \text { a } \\
(0.02)\end{array}$ & $\begin{array}{c}z 0.61 \text { a } \\
(0.04)\end{array}$ & $\begin{array}{l}0.74 \mathrm{~b} \\
(0.14)\end{array}$ & $\begin{array}{l}0.69 \mathrm{~b} \\
(0.11)\end{array}$ & $\begin{array}{l}0.58 \mathrm{a} \\
(0.01)\end{array}$ & $\begin{array}{c}\text { y } 0.70 \mathrm{~b} \\
(0.03)\end{array}$ & $\begin{array}{l}0.47 \mathrm{a} \\
(0.12)\end{array}$ \\
\hline & 4 & $\begin{array}{c}0.73 \mathrm{ab} \\
(0.11)\end{array}$ & $\begin{array}{c}\text { y } 0.85 \text { b } \\
(0.02)\end{array}$ & $\begin{array}{c}\text { y } 0.73 \\
\text { ab } \\
(0.04)\end{array}$ & $\begin{array}{l}0.68 \mathrm{a} \\
(0.08)\end{array}$ & $\begin{array}{l}0.69 c \\
(0.06)\end{array}$ & $\begin{array}{c}0.62 \mathrm{bc} \\
(0.06)\end{array}$ & $\begin{array}{c}\text { z } 0.38 \text { a } \\
(0.04)\end{array}$ & $\begin{array}{l}0.52 \mathrm{~b} \\
(0.05)\end{array}$ \\
\hline
\end{tabular}

* Mean fluorescent ratio values of three $(n=3)$ replicates; standard deviations are indicated in brackets.

** For each chilling storage time, pressure holding time and rigor mortis stage, means followed by different letters (a-c) indicate significant $(p<0.05)$ differences as a result of pressure. For each chilling storage time, pressure and rigor mortis stage, mean values preceded by different letters $(z, y)$ indicate significant $(p<0.05)$ differences as a result of pressure holding time. No letters are indicated when significant differences are not found $(p>0.05)$. 
throughout the storage time, a definite pattern related to the effect of the pressure applied could not be concluded ( $p>0.05)$. Previous research has shown an increasing FR value with pressure applied throughout the further chilling storage of Coho salmon (Aubourg et al., 2010); thus, pressure values of 200 and $175 \mathrm{MPa}$ led to higher fluorescent scores than those obtained for the control and 135-MPa-treated fish.

Concerning the pressure holding time effect, an increasing mean FR value could be depicted by increasing it in pre-RM samples when the previous pressure applied was 250 and 450 $\mathrm{MPa}$; and differences were found to be significant ( $p<0.05$ ) at days 2, 10 and 14. On the contrary, an inhibitory effect was observed in pre-RM fish when the pressure applied was $550 \mathrm{MPa}$; in such case, significant differences were found $(p<0.05)$ at days 2 and 10 .

The effect of HHP treatment on lipid oxidation development (primary, secondary and interaction compound formation) in fish can be considered somewhat controversial. Although most research has shown that an increased lipid oxidation development is to be produced as a result of the HHP treatment, isolated extracted lipids have shown to be relatively stable against oxidation under HHP conditions and during further storage (Ohshima et al., 1993; Angsupanich and Ledward, 1998). Additionally, the possible pro-oxidant effect of HHP treatment on muscle lipids was shown to be eliminated if a previous water washing of the muscle was applied or if a complex compound (EDTA, for example) was added. Consequently, iron-bound protein denaturation during HHP treatment has been reported to facilitate a free metal ion content increase and to be responsible for this lipid oxidation development in fish meat after HHP treatment.

According to the present study, two main HHPtreatment effects can be distinguished in lipid oxidation development during the chilled storage. According to previously mentioned research, HHP may lead to a pro-oxidant effect as a result of a free metal ion content increase, so that peroxide and TBARS formation could be favored. Additionally, HHP treatment has been reported to induce damages in the protein structure (Ramírez-Suárez and Morrisey, 2006), leading to an increasing reactivity of proteins towards electrophilic compounds and fluorescent compound formation (Aubourg, 1999; Tironi et al., 2002). On the other hand, the pressure treatment conditions (pressure level and pressure holding time) can lead to an inhibition of the prooxidant properties of fish endogenous enzymes (lipoxygenases, peroxydases, etc.) throughout a further processing or storage, and lead to a damage inhibition and shelf- life increase. In addition, a lower FR value has been observed to be produced after HHP treatment (day-0 fish). The results obtained in the present research for the three oxidation levels can be considered as the resulting values of both inverse effects.
Regarding the effect of the RM stage in the present research, lower mean FR values were observed at chilling time 0 in post-RM fish than in their pre-RM counterparts; significant differences were found ( $p<0.05$ ) in most HHP-treated fish. However, a definite pattern could not be concluded $(p>0.05)$ throughout the chilled storage for the RM stage whatever the HHP conditions applied were.

\section{CONCLUSIONS}

The present research provides a valuable lipid damage study concerning the employment of HHP technology followed by a subsequent chilling storage of an underutilized fish species. In addition, new information related to lipid hydrolysis and oxidation development is given concerning the effect of the RM stage of the initial raw material employed.

Thus, previous HHP treatment has led to a marked lipid hydrolysis inhibition in chilled Chilean jack mackerel. Both an increasing pressure level as well as an increasing pressure holding time led to a lower FFA content in fish muscle, with the effect of pressure being more relevant. As a result of the different factors encountered in lipid oxidation development, a definite effect of HHP conditions (pressure level and pressure holding times) on lipid oxidation evolution (primary, secondary and interaction compound formation assessment) in chilled Chilean jack mackerel could not be concluded. Concerning the effect of the RM stage of the starting raw fish, the differences found showed that in most cases processing of fish before the RM stage takes place is more convenient.

According to the present study, the suggestion of better HHP conditions to be employed before a subsequent chilled storage of Chilean jack mackerel would be based mostly on the lipid hydrolysis results. Thus, a relatively high-pressure value (namely, $450 \mathrm{MPa}$ ) and the longest pressure holding time tested (namely, $4 \mathrm{~min}$ ) would be recommended. In addition, the employment of preRM fish would be highly recommended. However, and in order to definitely choose the best HHP conditions to be applied to the actual fish species, complementary analyses concerning sensory acceptance and microbiological development ought to be carried out.

\section{ACKNOWLEDGEMENTS}

The authors wish to thank Mr. Marcos Trigo and Mrs. Cristina Nine for their excellent technical assistance. The study was carried out according to the funding provided by FONDECYT (Chile; Project 1110782) and by the Secretaría Xeral de I+D from the Xunta de Galicia (Galicia, Spain) through the Research Project 10TAL402001PR (2010-2012). 


\section{REFERENCES}

Alizadeh E, Chapleau N, de Lamballerie M, Le Bail A. 2007. Effect of different freezing processes on the microstructure of Atlantic salmon (Salmo salar) fillets. Innov. Food Sci. Emerg. Technol. 8, 493-499.

Amanatidou A, Schlüter O, Lemkau K, Gorris L, Smid E, Knorr D. 2000. Effect of combined application of high pressure treatment and modified atmospheres on the shelf life of fresh Atlantic salmon. Innov. Food Sci. Emerg. Technol. 1, 87-98.

Angsupanich K, Ledward D. 1998. High pressure treatment effects on cod (Gadus morhua) muscle. Food Chem. 63, 39-50.

Antipova N, Smirnova G. 1982. Changes in the composition of lipids in stellate sturgeon in relation to its post mortem condition. Rybnoe Khozyaistvo 3, 70-71.

Aranda M, Mendoza N, Villegas R. 2006. Lipid damage during frozen storage of whole jack mackerel (Trachurus symmetricus murphyi). J. Food Lipids 13, 155-166.

Aubourg S, Pérez-Martín R. 1996. Fluorescent compound formation during sardine (Sardina pilchardus) chilling: Comparison with lipid damage indexes. Grasas Aceites 47, 307-312.

Aubourg S, Tabilo-Munizaga G, Reyes J, Rodríguez A, Pérez-Won M. 2010. Effect of high-pressure treatment on microbial activity and lipid oxidation in chilled Coho salmon. Eur. J. Lipid Sci. Technol. 112, 362-372.

Aubourg S. 1999. Effect of lipid damages on processed fish quality. Grasas Aceites 50, 218-224.

Birkeland S, Akse L. 2010. Study of the quality characteristics in cold-smoked salmon (Salmo salar) originating from pre- or post-rigor raw material. $J$. Food Sci. 75, E580-E587.

Bligh E, Dyer W. 1959. A rapid method of total extraction and purification. Can. J. Biochem. Physiol. 37, 911917.

Bórquez R, González C. 1994. Influence of acetic acid preservation of Chilean mackerel (Trachurus murphyi) on fish meal production. J. Sci. Food Agric. 66, 187192.

Chaouqy N, Gallardo J, El Marrakchi A, Aubourg S. 2008. Lipid damage development in anchovy (Engraulis encrasicholus) muscle during storage under refrigerated conditions. Grasas Aceites 59, 309-315.

Chapman R, McKay J. 1949. The estimation of peroxides by the ferric thiocyanate method. J. Amer. Oil Chem. Soc. 26, 360-363.

Chevalier D, Le Bail A, Ghoul M. 2001. Effects of high pressure treatment (100-200 MPa) at low temperature on turbot (Scophthalmus maximus) muscle. Food Res. Int. 34, 425-429.

Duran A, Erdemli U, Karakaya M, Yilmaz M. 2008. Effect of slaughter methods on physical, biochemical and microbiological quality of rainbow trout Oncorhynchus mykiss and mirror carp Cyprinus carpio filleted in preor post-rigor periods. Fisher. Sci. 74, 1146-1155.

Erkan N, Üretener G, Alpas H, Selçuk A, Özden Ö, Buzrul S. 2011. Effect of high hydrostatic pressure (HHP) treatment on physicochemical properties of horse mackerel (Trachurus trachurus). Food Bioprocess Technol. 4, 1322-1329.

Erkan N, Üretener G, Alpas H. 2010. Effect of high pressure (HP) on the quality and shelf life of red mullet (Mullus surmelutus). Innov. Food Sci. Emerg. Technol. 11, 259-264.

FAO. 2007. Fishery statistics. Capture Production. In Food and Agriculture Organization of the United
Nations, Yearbook 2005, Vol 100/1, p. 79, Rome, Italy.

Gómez-Estaca J, Montero P, Jiménez B, Gómez-Guillén MC. 2007. Effect of functional edible films and high pressure processing on microbial and oxidative spoilage in cold-smoked sardine (Sardina pilchardus). Food Chem. 105, 511-520.

$\mathrm{He} \mathrm{H}$, Adams R, Farkas D, Morrisey MT. 2002. Use of high-pressure processing for oyster shucking and shelf-life extension. J. Food Sci. 67, 640-645.

Hurtado J, Montero P, Borderías AJ. 2001. Chilled storage of pressurized octopus (Octopus vulgaris) muscle. J. Food Sci. 66, 400-406.

Lakshmanan R, Parkinson J, Piggott J. 2007. Highpressure processing and water-holding capacity of fresh and cold-smoked salmon (Salmo salar). Food Sci. Technol. 40, 544-551.

Lowry R, Tinsley I. 1976. Rapid colorimetric determination of free fatty acids. J. Amer. Oil Chem. Soc. 53, 470472.

Montero P, Pérez-Mateos M, Borderías AJ. 1998. Chilled storage of high pressure and heat-induced gels of blue whiting (Micromesistius poutassou) muscle. $Z$. Lebensm. Unters. Forsch. 207, 146-153.

Norton T, Sun DW. 2008. Recent advances in the use of high pressure as an effective processing technique in the food industry. Food Bioprocess Technol. 1, 2-34.

Ohshima T, Nakagawa T, Koizumi C. 1992. Effect of high hydrostatic pressure on the enzymatic degradation of phospholipids in fish muscle during storage, in Bligh E (Ed.) Seafood Science and Technology. Fishing News Books, Oxford, UK, pp. 64-75.

Ohshima T, Ushio H, Koizumi C. 1993. High-pressure processing of fish and fish products. Trends Food Sci. Technol. 4, 370-375.

Ortea I, Rodríguez A, Tabilo-Munizaga G, Pérez-Won M, Aubourg S. 2010. Effect of hydrostatic high-pressure treatment on proteins, lipids and nucleotides in chilled farmed salmon (Oncorhynchus kisutch) muscle. Eur. Food Res. Technol. 230, 925-934.

Ortiz J, Aguilera JM. 2004. Effect of kappa-carrageenan on the gelation of horse mackerel (Trachurus murphyi) raw paste surimi-type. Food Sci. Technol. Intern. 10, 223-232.

Quitral V, Donoso M느, Ortiz J, Herrera $M^{2}$ V , Araya $H$, Aubourg S. 2009. Chemical changes during the chilled storage of Chilean jack mackerel (Trachurus murphyi): Effect of a plant extract-icing system. Food Sci. Technol. 42, 1450-1454.

Ramírez R, Saraiva J, Pérez Lamela C, Torres JA. 2009. Reaction kinetics analysis of chemical changes in pressure-assisted thermal processing. Food Eng. Rev. 1, 16-30.

Ramírez-Suárez J, Morrisey M. 2006. Effect of high pressure processing (HPP) on shelf life of albacore tuna (Thunnus alalunga) minced muscle. Innov. Food Sci. Emerg. Technol. 7, 19-27.

Refsgaard H, Brockhoff P, Jensen B. 2000. Free polyunsaturated fatty acids cause taste deterioration of salmon during frozen storage. J. Agric. Food Chem. 48, 1136-1140.

Roth B, Slinde E, Arildsen J. 2006. Pre and post mortem muscle activity in Atlantic salmon (Salmo salar). The effect on rigor mortis and the physical properties of flesh. Aquaculture 257, 504-510.

Rouillé J, Le Bail A, Ramaswamy H, Leclerc L. 2002. High pressure thawing of fish and shellfish. J. Food Engin. 53, 83-88. 
Sánchez J, De Miguel C, Ramírez R, Delgado J, Franco M, Martín D. 2012. Effect of high hydrostatic pressure versus thermal pasteurization on the microbiological, sensory aspects and oxidative stability of olive pate. Grasas Aceites 63, 100-108.

Schoebitz R, Tamayo R, Davis M. 1985. Microbiological quality of the fish species Trachurus murphyi, sold at the retail level in the town of Valdivia, Chile. Food Microb. 2, 243-247.

Sequeira-Muñoz A, Chevalier D, Le Bail A, Ramaswamy H, Simpson J. 2006. Physicochemical changes induced in carp (Cyprinus carpio) fillets by high pressure processing at low temperature. Innov. Food Sci. Emerg. Technol. 7, 13-18.

Sikorski Z, Kolakowska A. 1994. Changes in protein in frozen stored fish, in Sikorski Z, Sun Pan B, Shahidi $F$ (Eds.) Seafood proteins. Chapman and Hall, New York, USA, pp. 99-112.

Simpson R, Almonacid S, Mitchell M. 2004. Mathematical model development, experimental validation and process optimisation: retortable pouches packed with seafood in cone frustum shape. J. Food Eng. 63, 153162.

Tanaka M, Xueyi Z, Nagashima Y, Taguchi T. 1991. Effect of high pressure on the lipid oxidation in sardine meat. Nippon Suisan Gakkaishi 57, 957-963.
Tironi V, Tomás M, Añón Mạ C. 2002. Structural and functional changes in myofibrillar proteins of sea salmon (Pseudopercis semifasciata) by interaction with malondialdehyde (RI). J. Food Sci. 67, 930-935.

Torres JA, Velázquez G. 2005. Commercial opportunities and research challenges in the high pressure processing of foods. J. Food Eng. 67, 95-112.

Vázquez M, Torres JA, Gallardo JM, Saraiva JA. Aubourg S. 2013. Lipid hydrolysis and oxidation development in frozen mackerel (Scomber scombrus): Effect of a high hydrostatic pressure pre-treatment. Innov. Food Sci. Emerg. Technol. 18, 24-30.

Vyncke W. 1970. Direct determination of the thiobarbituric acid value in trichloroacetic acid extracts of fish as a measure of oxidative rancidity. Fette, Seifen, Anstrichm. 72, 1084-1087.

Whittle K, Hardy R, Hobbs G. 1990. Chilled fish and fishery products, in Gormley T (Ed.) Chilled foods: the state of the art. Elsevier Applied Science, New York, USA, pp. 87-116.

Yagiz Y, Kristinsson H, Balaban M, Marshall M. 2007. Effect of high pressure treatment on the quality of rainbow trout (Oncorhynchus mykiss) and mahi mahi (Coryphaena hippurus). J. Food Sci. 72, C509-C515.

Recibido: $16 / 1 / 13$ Aceptado: $17 / 5 / 13$ 